\title{
PERANCANGAN APLIKASI SMART SEMINAR DAN WORKSHOP BERBASIS WEBSITE
}

\author{
Abdul Hamid Arribathi ${ }^{* 1}$, Saryani $^{2}$ Haris $^{3}$ \\ ${ }^{1,2}$ Program Studi Sistem Informasi Universitas Raharja, ${ }^{3}$ Program Stud Tekhnik \\ Informatika Universitas Raharja \\ e-mail : ${ }^{1 *}$ abdulhamid@ raharja.info, ${ }^{2}$ saryani@ raharja.info, ${ }^{3}$ haris@ @aharja.info
}

\begin{abstract}
Seminars and workshops are inseparable activities from the world of education in higher education. As the implementation of the Tridharma of Higher Education is teaching, research and service. The results of the research conducted require publication through writing or seminars and workshops. However, there are still many seminars and workshops that hold it conventionally starting from the announcement of the event, registration of participants, to the process of implementing the event. So that it feels less effective. Therefore a Smart Seminar and web and Android based Workshop system is needed, which can facilitate the announcement of events and registration of participants online, absent attendees with QRCode, and make participants able to ask questions directly through the application without interrupting the content being conveyed by the speaker. The research method that was carried out in the first stage was collecting data and information through interviews, literature studies, and Focus Group Discussion (FGD) with seminar and workshop experts. The second stage is to build the system using the Waterfall type SDLC (System Development Life Cycle) method. The Waterfall Model provides a sequential or sequential software lifecycle approach starting from analysis, design, coding, testing, and maintenance. The results of the Smart Seminar and Worksop system design can facilitate educational institutions in conducting seminars and workshops effectively and more quality, as well as more interactive between participants and speakers in terms of questions and answers. This application can be accessed via a web browser or with an Android application.
\end{abstract}

Keywords : Smart Seminars and Workshops, Absent QRCode, Online Questions and Answers

\begin{abstract}
ABSTRAKSI
Seminar dan workshop merupakan kegiatan yang tak terpisahkan dari dunia pendidikan di perguruan tinggi. Sebagaimana pelaksanaan tridharma perguruan tinggi adalah pengajaran, penelitian dan pengabdian. Hasil penelitian yang dilakukan memerlukan publikasi melalui tulisan ataupun seminar dan workshop. Namun pelaksanaan seminar dan workshop tersebut masih banyak yang menyelenggarakannya secara konvensional mulai dari pengumuman acara, pendaftaran peserta, hingga proses pelaksanaan acara. Sehingga dirasakan kurang efektif. Oleh karena itu, dibutuhkan sistem Smart Seminar dan Workshop berbasis web dan android, yang dapat memfasilitasi pengumuman acara dan pendaftaran peserta secara online, absen kehadiran peserta dengan QRCode, serta membuat peserta dapat bertanya langsung melalui aplikasi tanpa menyela isi materi yang sedang disampaikan oleh pembicara. Metode penelitian yang dilakukan tahap pertama mengumpulkan data dan informasi melalui wawancara, studi pustaka, dan Focus Group Discussion (FGD) dengan para pakar seminar dan workshop. Tahap kedua, untuk membangun sistem ini digunakan metode SDLC (System Development Life Cycle) jenis Waterfall. Model Waterfall menyediakan pendekatan alur hidup perangkat lunak secara sekuensial atau terurut dimulai dari analisis, desain,
\end{abstract}


pengodean, pengujian, dan pemeliharaan. Hasil rancang bangun sistem Smart Seminar dan Worksop dapat memudahkan institusi pendidikan dalam pelaksanaan seminar dan workshop secara efektif dan lebih bekualitas, serta lebih interaktif antara peserta dengan pembicara dalam hal tanya jawab. Aplikasi ini dapat diakses melalui web browser maupun dengan aplikasi Android.

Keyword: Smart Seminar dan Workshop, Absen QRCode, Tanya Jawab Online

\section{PENDAHULUAN}

Dalam dunia pendidikan yang semakin berkembang pesat hal ini diikuti juga dengan perkembangan dalam bidang teknologi yang menuntut adanya kemudahan, kecepatan, keakuratan dan juga keamanan dalam mengakses maupun mengolah suatu sistem, menurut Sutarman, tahun 2012 sistem adalah kumpulan elemen yang saling berhubungan dan berinteraksi dalam satu kesatuan untuk menjalankan suatu proses pencapaian suatu tujuan utama informasi. Pada prosesnya dunia pendidikan tidak terlepas dari tridharma perguruan tinggi yang terdiri dari pengajaran, penelitian dan pengabdian pada masyarakat, dalam bidang penelitian, dosen memerlukan publikasi hasil penelitian baik melalui tulisan berupa prosiding, jurnal, buku ajar, maupun melalui seminar atau workshop untuk menyampaikan hasil penelitian kepada para dosen dan mahasiswa ataupun kepada masyarakat umum, agar hasil penelitiannya dapat bermanfaat bagi dunia pendidikan dan masyarakat pada umumnya. Bagi dunia pendidikan, khususnya kampus sudah sering mengadakan seminar dan workshop, namun pelaksanaan seminar dan workshop tersebut masih banyak yang menyelenggarakannya secara konvensional mulai dari pengumuman acara, pendaftaran peserta, hingga proses pelaksanaan acara. Sehingga dirasakan kurang efektif dan tidak berkelanjutan dengan tanya jawab yang dapat meningkatkan kualitas acara. Secara konvensional panitia acara mengumumkan waktu dan tanggal pelaksanaan acara seminar maupun workshop, lalu calon peserta mendaftarkan diri ke panitia dan membayar biaya acara. Pada saat hari pelaksanaan acara, peserta yang datang menuliskan nama dan tandatangan kehadirannya pada buku peserta acara yang telah disediakan. Begitu pula saat pembicara menyampaikan isi materinya, peserta menanyakan langsung pada pembicara mengenai hal yang tidak dipahami atau perlu penjelasan lebih banyak, sehingga membuat penyampaian materi terputus dan dapat mengakibatkan tidak tuntasnya materi yang disampaikan. Untuk itu perlu ada solusi, untuk menyelesaian permasalahan pada proses seminar dan workshop diantaranya adalah dengan perancangan sistem smart seminar dan workshop berbasis website, yang dapat memfasilitasi pengumuman acara dan pendaftaran peserta secara online, absen kehadiran peserta dengan QRCode, serta membuat peserta dapat bertanya langsung melalui aplikasi tanpa menyela isi materi yang sedang disampaikan oleh pembicara.

\section{TINJAUAN PUSTAKA}

\section{Seminar dan Workshop \\ Seminar}

Menurut Kamus Besar Bahasa Indonesia, seminar adalah pertemuan atau persidangan untuk membahas suatu masalah di bawah pimpinan ahli (Guru Besar, Pakar, dan sebagainya). Definisi yang lebih umum dari seminar adalah sebuah bentuk pengajaran yang diberikan secara khusus untuk membahas suatu topik tertentu yang mana pelaksanaannya bisa dilakukan oleh sebuah lembaga profesional ataupun oleh organisasi komersil lainnya.

Seminar dilaksanakan dengan cara menerapkan sistem pengajaran akademis, dimana kegiatan ini dilakukan seperti layaknya sebuah kelas perkuliahan bagi pesertanya. Pada umumnya sebuah seminar akan membahas sebuah topik khusus yang mana para peserta dapat berpartisipasi secara aktif di dalam pembahasan tersebut. 
Peserta seminar bukanlah orang-orang yang baru di dalam topik yang sedang dibahas, tetapi mereka adalah orang yang telah terbiasa atau setidaknya mengenal dengan baik topik yang akan dibahas dalam seminar tersebut. Hal ini akan memudahkan terciptanya dialog di antara peserta seminar dengan pembicara yang didatangkan oleh panitia pelaksana.

\section{Workshop}

Definisi workshop adalah sebuah kegiatan atau acara yang dilakukan, dimana beberapa orang yang memiliki keahlian di bidang tertentu berkumpul untuk membahas masalah tertentu dan mengajari para peserta. Workshop dapat juga diartikan sebagai latihan dimana peserta bekerja secara individu maupun secara kelompok untuk menyelesaikan pekerjaan yang berkaitan dengan tugas yang sebenarnya untuk mendapatkan pengalaman. Sehingga, workshop merupakan gabungan antara teori dan praktek.

Dalam sebuah workshop, sekelompok orang yang memiliki minat atau perhatian dan keahlian yang sama di bidang tertentu berkumpul, dimana kegiatan mereka akan dibawah arahan beberapa ahli untuk menggali satu atau beberapa aspek khusus suatu pembahasan masalah.

Salah satu contoh workshop adalah workshop mengenai penyusunan kurikulum KKNI (Kerangka Kualifikasi Nasional Indonesia), dimana dalam workshop tersebut dilaksanakan untuk mengenalkan atau menjelaskan perubahan kurikulum di dalam mendesain kurikulum perguruan tinggi.

Definisi Aplikasi

Berikut adalah beberapa definisi aplikasi Menurut Tantowi Yahya, Radna Nurmalina (2015) dalam jurnal Sains Dan Informatika "Perangkat lunak aplikasi adalah suatu sub kelas perangkat lunak komputer yang memanfaatkan kemampuan komputer langsung untuk melakukan suatu tugas yang diinginkan pengguna".

Definisi Webite

Menurut Ilka Zufria dan M. Hasan Azhari (2017) "Website adalah sekumpulan halaman informasi dan data yang disediakan melalui jaringan internet sehingga dapat diakses di seluruh dunia. Website merupakan sebuah komponen yang terdiri dari gambar, teks, suara animasi sehingga menjadi media informasi yang cukup menarik untuk dikunjungi oleh pengguna

internet.

Menurut Fitri Marisa (2016 ) "Web adalah kumpulan halaman yang digunakan untuk mempublikasikan informasi dan data bisasanya bisa berupa gambar,teks atau program multimedia lainnya.

Andriod

Menurut Ni Kadek C.D., dkk. Android merupakan sistem operasi mobile. Android tidak membedakan antara aplikasi inti dengan aplikasi pihak ketiga. Application Programming Interface (API) yang disediakan menawarkan akses ke hardware, maupun data data ponsel sekalipun, atau data sistem sendiri. Menurut Supardi yang dikutip oleh Ni Kadek C.D., dkk dalam jurnal SINTECH JOURNAL Android merupakan sebuah sistem operasi perangkat mobile berbasis linux yang mencangkup sistem operasi, middleware, dan aplikasi. Beberapa pengertian lain dari Android, yaitu :

Merupakan platform terbuka (Open Source) bagi para pengembang (Programer) untuk membuat aplikasi.

Merupakan sistem operasi yang dibeli Google Inc. dari Android Inc.

Bukan bahasa pemrograman, tetapi hanya menyediakan lingkungan hidup atau run time enviroment yang disebut DVM (Dalvik Virtual Machine) yang telah dioptimasi untuk alat/device dengan sistem memori yang kecil. 


\section{METODOLOGI}

Dalam penelitian ini, analisa dilakukan langsung di Universitas Raharja Tangerang. Menurut Rosa dan Shalahuddin (2018) model waterfall adalah "metode air terjun menyediakan pendekatan alur hidup perangkat lunak secara sekuensial atau terurut dimulai dari analisa, desain, pengkodean, pengujian, dan pemeliharaan". Untuk membangun Sistem Smart Seminar dan Workshop ini akan menggunakan metode penelitian yang meliputi Metode Pengumpulan Data, Metode Pengembangan Sistem, Arsitektur Sistem Smart Seminar dan Workshop, teknik pengumpulan data untuk pengembangan sistem, dan pengembangan antar muka pengguna (user interface). Pada beberapa penelitian menggunakan metode kualitatif, dapat dijelaskan pendekatan yang digunakan, proses pengumpulan dan analisis informasi, dan proses penyimpulan hasil penelitian. Metode pengumpulan data dilakukan dengan proses wawancara, Metode penelitian yang digunakan adalah metode SDLC (System Development Life Cycle) jenis Waterfall yang cocok untuk menggambarkan sistem, Berdasarkan data tahap pertama, akan didesain dan diimplementasikan sistem Smart Seminar dan Workshop serta diujicobakan serta diterapkan dan dilakukan pemeliharaan sistem di kampus. seperti yang disajikan pada gambar 1.

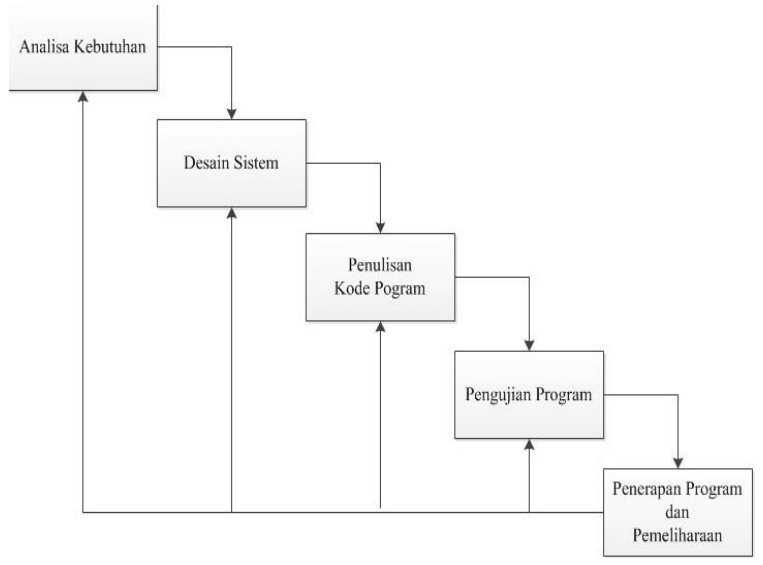

Gambar 1. Metodologi Waterfall

\section{HASIL DAN PEMBAHASAN}

Arsitektur Sistem Smart Seminar dan Workshop

Sistem Smart Seminar berbasis Website ini terdiri bagian Server dan bagian Client. Pada bagian Server menggunakan web server Apache, PHP Engine dan DBMS MySQL. Layanan pada server berupa web service dengan response data JSON (JavaScript Object Notation). Pada sisi Client dari Aplikasi ini, pengguna dapat mengakses Smart Seminar melalui web browser maupun aplikasi Android : 


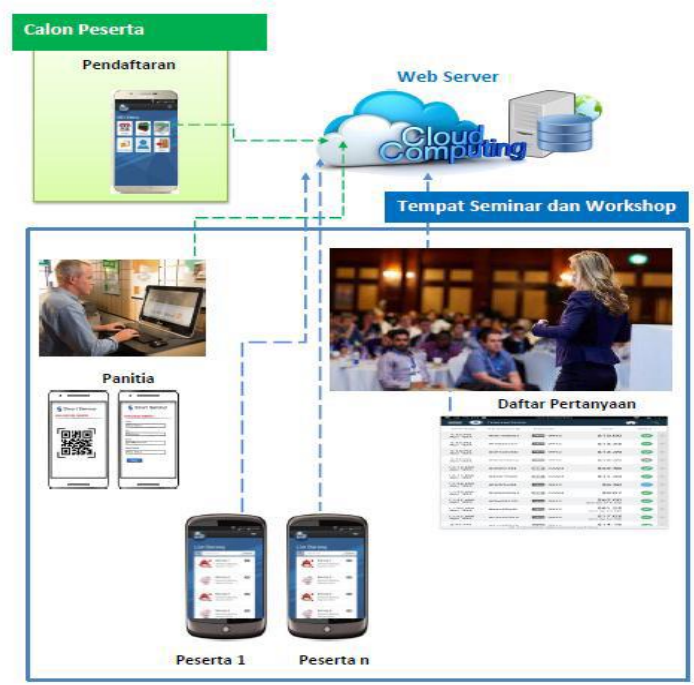

Gambar 4.1 Arsitektur Sistem Smart Seminar dan Workshop

Tampilan Prototype Antar Muka Pengguna

Antarmuka sistem dirancang untuk memudahkan pemakai dalam menggunakan sistem yang akan dikembangkan, sehingga lebih user friendly. Sistem Smart Seminar didesain mempunyai dua tampilan yang berbeda bagi Panitia dan Peserta. Rancangan antarmuka aplikasi ini meliputi:

1. Tampilan Halaman Login
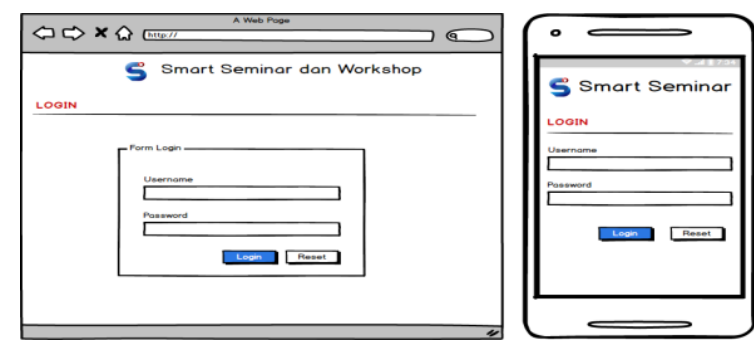

Gambar 4.2 Tampilan Halaman Login

Berisi informasi Aplikasi dan Form Login untuk otentikasi pengguna yang akan menggunakan sistem ini, Antarmuka sistem dirancang dengan tampian login untuk masuk ke menu utama

2. Tampilan Daftar Acara 


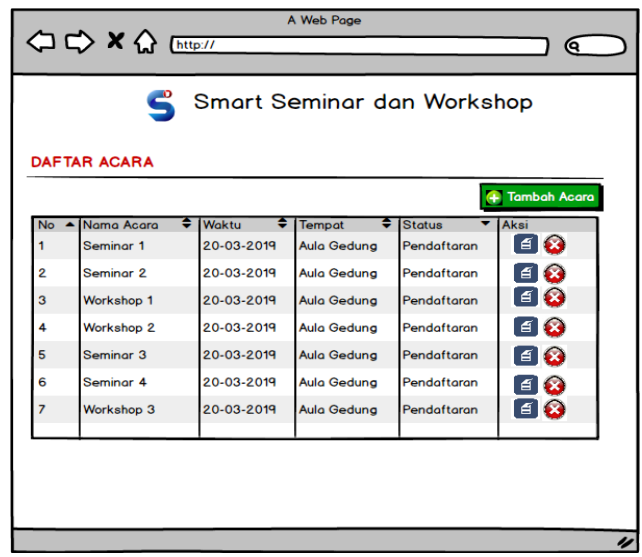

Gambar 4.3 Tampilan Daftar Acara

Tampilan daftar acara meliputi antar muka sistem yang dirancang untuk memudahkan peserta dalam menentukan daftar acara yang akan dipilih oleh peserta seminar dan workshop

3. Tampilan Form Tambah dan Edit Acara

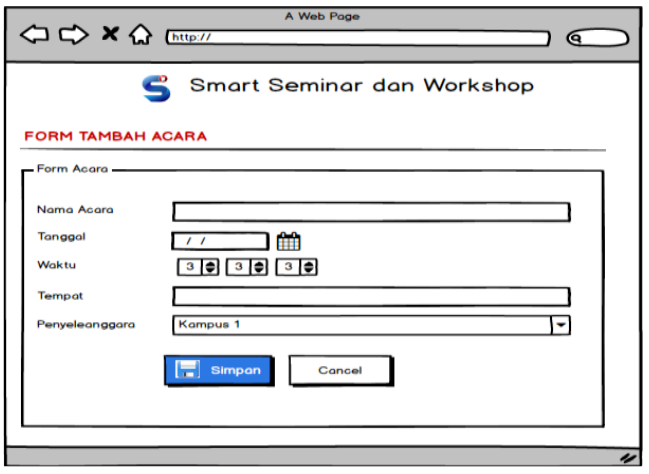

Gambar 4.4 Tampilan Form Tambah dan Edit Acara

Tampilan ini dirancang untuk keperluan pengguna dalam menambah acara maupun mengedit acara yang telah dipilih sebelumnya jika ada kesalahan dalam penginputan sebelumnya

4. Tampilan Pendaftaran Acara

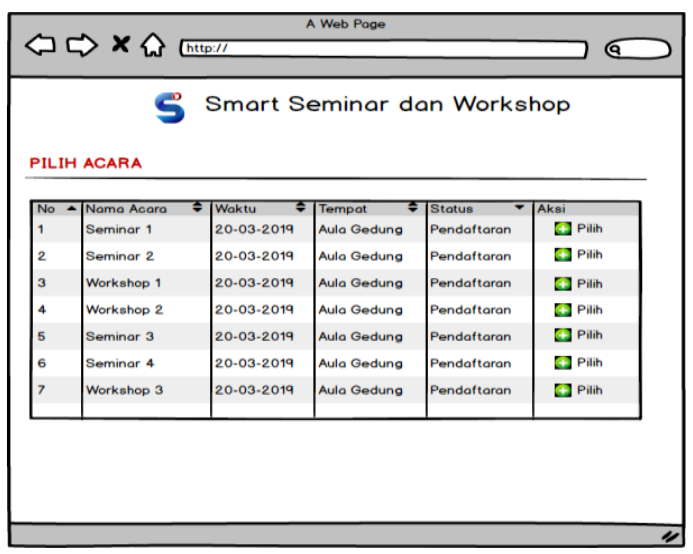

Gambar 4.5 Tampilan Pendaftaran Acara 
Tampilan antar muka ini memudahkan peserta dalam memilih berbagai acara seminar dan workshop dilengkapi waktu, tempat dan status pendaftaran.

5. Tampilan Pendaftaran Acara Mobile

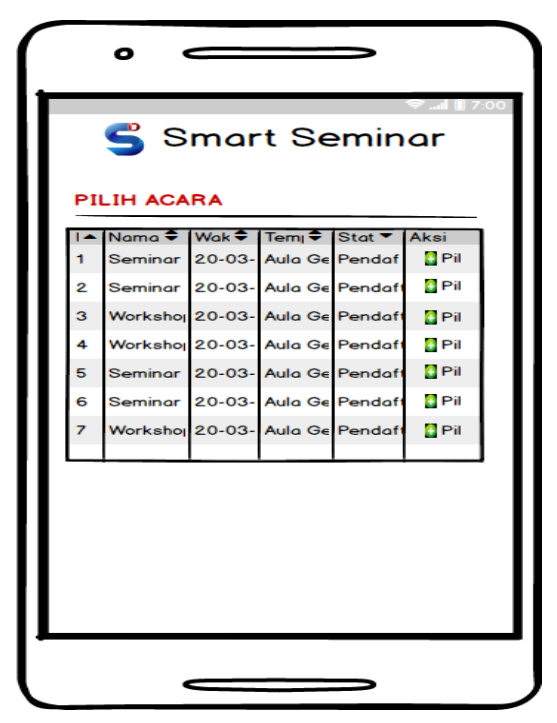

Gambar 4.6 Tampilan Pendaftaran Acara Mobile

Tampilan ini bisa dibuka menggunakan smartphone sehingga lebih memudahkan para peserta.

6. Tampilan Register Peserta

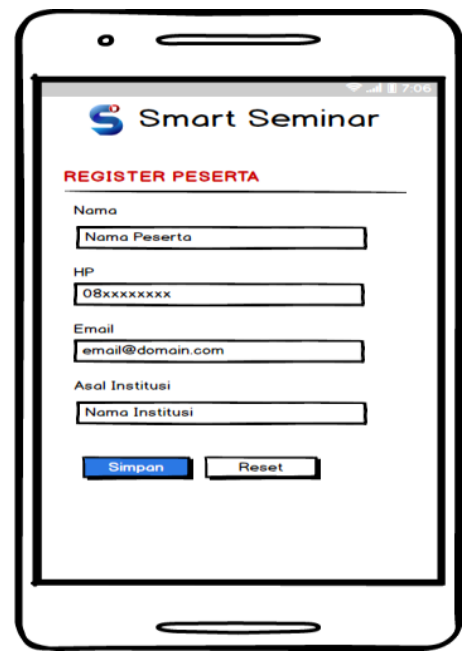

Gambar 4.7 Tampilan Register Peserta

Tampilan ini disajikan untuk para peserta dalam prses registrasi secara online.

7. Tampilan Absen Kehadiran 


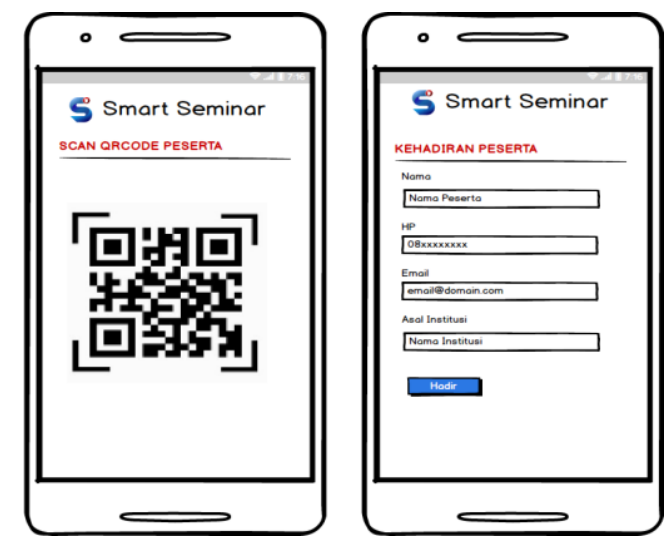

Gambar 4.8 Absen Kehadiran QRcode

Tampilan gambar diatas merupakan tampilan absensi kehadiran peserta menggunakan

8. Tampilan Form Pertanyaan

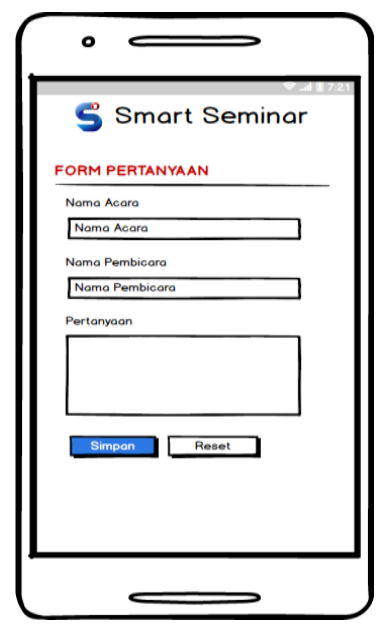

Gambar 4.9 Tampilan Form Pertanyaan

Gambar antar muka diatas merupakan tampilan daftar pertanyaan peserta yang bisa dilakukan secara online tanpa menunggu acara selesai

9. Tampilan Jawab Pertanyaan

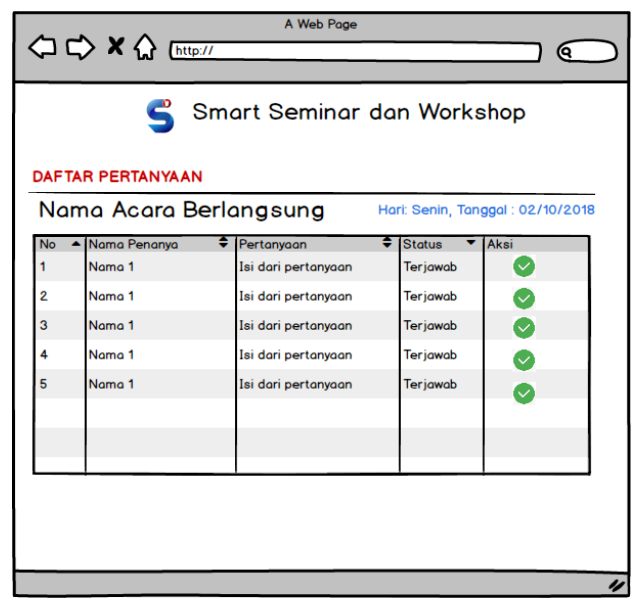

Gambar 4.10 Tampilan jawab pertanyaan 
Tampilan diatas merupakan tampilan jawaban dari panitia seminar dan workshop dalam menyelesaikan permasalahan peserta.

\section{KESIMPULAN}

Dengan adanya sistem perancangan Smart Seminar dan Workshop berbasis website ini akan sangat membantu penyelenggaraan pada seminar dan workshop karena dapat menyelesaikan permasalahan seputar pelaksaanaan seminar dan workshop yang masih banyak menggunakan sistem manual sehingga dalam penelitian ini bisa memberikan solusi terhadap masalah yang terjadi pada panitia dan peserta sehingga dapat memberikan informasi seputar pengumuman acara dan pendaftaran peserta secara online, dapat menghindari absensi fiktif, karena absen kehadiran peserta menggunakan QRCode yang dikirim ke email masing-masing, serta peserta dapat bertanya langsung melalui aplikasi tanpa menyela isi materi yang sedang disampaikan oleh pembicara.

\section{DAFTAR PUSTAKA}

[1]. Sutarman. 2012. "Pengantar Teknologi Informasi”.Jakarta:Bumi Aksara.

[2]. Yahya, Tantowi dan Radna Nurmalina. 2015. "Aplikasi Pendataan Gudang Pupuk Di Dinas Pertanian Tanaman Dan Perkebunan. Kalimantan Selatan:Jurnal Sains Dan Informatika". Vol.1 No.2:58-61.

[3]. Priana, Isan dan Leni Fitriani. 2016." Perancangan Aplikasi Perangkat Lunak Pengelolaan Data Bank Sampah di PT. Inpower Karya Mandiri Garut”. Garut:Jurnal Algoritma. Vol.14 No.1:407-413.

[4]. Zufria, Ilka dan M. Hasan Azhari. 2017. "Web-Based Applications in Calculation of Family Heritage (Science of Faroidh)". Jurnal Sistem Informasi Vol.1 No.1.

[5]. Marisa, Fitri. 2016. Web Programing (Client Server and Server Side). Yogyakarta: CV Budi Utama.

[6]. C.D.Ni Kadek, G.A. Ida Bagus, Atmaja K.J., dan, W.A. Putu . 2018. "RANCANG BANGUN APLIKASI MOBILE SISKA BERBASIS ANDROID”. SINTECH JOURNAL. Vol.1 No.2.

[7]. Rosa A. S dan M. Shalahuddin . 2018. "Rekayasa Perangkat Lunak Terstruktur Dan Berorientasi Objek”. Bandung. Penerbit Informatika Bandung. ISBN: 978-602-6232-65- 